\title{
Serum alkaline phosphatase in adult coeliac disease
}

\author{
O. D. HARRIS, MARY WARNER, AND W. T. COOKE \\ From the Nutritional and Intestinal Unit, The General Hospital, Birmingham
}

SUMmaRY The total alkaline phosphatase levels were determined in 118 patients with adult coeliac disease, 65 of whom had evidence of osteomalacia.

The secretor and blood group status, intestinal isoenzyme, and liver alkaline phosphatase played no significant part in the levels of serum alkaline phosphatase found.

There was a significant correlation between the levels of serum alkaline phosphatase and the presence of osteomalacia.

There is evidence that the serum level of alkaline phosphatase is compounded of isoenzymes arising from bone, liver, intestine, and, during pregnancy, from the placenta. In the intestinal mucosa, alkaline phosphatase is localized mainly in the brush border (Holt and Miller, 1962; Clark and Porteous, 1963). Rieken, Stewart, Booth, and Pearse (1966) found apparently normal concentrations of this enzyme in the intestinal epithelium of untreated patients with adult coeliac disease. They therefore suggested that there must be a compensating increased production of alkaline phosphatase to allow this in the presence of the severe morphological abnormalities encountered. Ferguson, Watson, Maxwell, and Fell (1968) found the mean concentration of alkaline phosphatase per gram of mucosa considerably less than normal though the concentration in some patients with 'villous atrophy' did fall within the range of the normal control observations. Observations on the clinical significance of intestinal alkaline phosphatase in interpreting serum levels are few. Pulvertaft, Luffman, Robson, Harris, and Langman (1967) could find no significant increase in postgastrectomy conditions. However, Dent, Norris, Smith, Sutton, and Temperley (1968) have reported a striking increase of plasma alkaline phosphatase of intestinal origin in a 29 -year-old man with marked steatorrhoea of undetermined aetiology.

The purpose of this investigation was to determine the clinical significance of the serum levels of total alkaline phosphatase and the contribution that might be made by the intestinal isoenzyme to this level in adult coeliac disease.

\section{METHODS}

Total serum alkaline phosphatase was determined by AutoAnalyzer method no. 9. The normal upper limit for men and women up to the age of 50 was 13 KingArmstrong units and 14 units up to the age of 60 (Roberts, 1967). The intestinal component was determined by a modification of the cellulose acetate method (Korner, 1962). Quantitative inhibition of alkaline phosphatase was performed with 0.01 M L-phenylalanine (Fishman, Green, and Inglis, 1963). Serum 5-nucleotidase was estimated by the automated method of Hill and Sammons (1966). Secretor status was determined by the method of Boyd and Shapleigh (1954) and ABO blood groups by a standard agglutination technique.

\section{CLINICAL MATERIAL}

One hundred and eighteen patients (59 men and 59 women, with a mean age of 46 years, and a mean duration of adult coeliac disease of 22 years) were diagnosed as suffering from adult coeliac disease, each having a characteristic flat jejunal biopsy and associated clinical and laboratory findings as set out by Cooke (1968). Sixty-five patients (28 men and 37 women, with a mean age of 47 years, and a mean duration of adult coeliac disease of 27 years) had osteomalacia, 41 of whom also had osteoporosis and seven had osteoporosis only (Harris and Cooke, 1968).

The significant feature for the diagnosis of osteomalacia in 16 patients was the urinary excretion of less than $50 \mathrm{mg}$ calcium per day and a raised serum level of alkaline phosphatase, falling on calciferol administration; in 44 patients histological evidence of increased osteoid tissue in the biopsy from the iliaccrest; and in five patients, who fulfilled the biochemical criteria but did not have bone biopsy, the presence of Looser's zones. The presence of osteoporosis was based on the radiological findings using bone scores as devised by Barnett and Nordin (1960) and bone histology. Only one had evidence of liver disorder and none had Paget's disease or was pregnant. Blood samples were collected during the midafternoon under comparable conditions while the patients were taking either a normal or a gluten-free diet. 


\section{RESULTS}

SERUM TOTAL ALKALINE PHOSPHATASE The distribution of the serum levels of total alkaline phosphatase is given in Table I. The mean level for the

\section{TABLE I}

DISTRIBUTION OF SERUM ALKALINE PHOSPHATASE LEVELS IN 118 PATIENTS WITH ADULT COELIAC DISEASE WITH OR WITHOUT OSTEOMALACIA

\begin{tabular}{lcc}
$\begin{array}{l}\text { Serum Total Alkaline } \\
\text { Phosphatase Level }(K-A \text { units) }\end{array}$ & $\begin{array}{l}\text { Osteomalacia } \\
\text { Osteoporosis }\end{array}$ \\
\hline 13 & 2 & 40 \\
13 to 17 & 10 & 4 \\
17 & 53 & 2
\end{tabular}

65 patients with osteomalacia was $27 \cdot 2$ KingArmstrong units. In two of these, the levels were normal, being 10 and 13 units respectively. (The diagnoses in these two patients were based on positive bone biopsies and increased urinary excretion of hydroxyproline.) In 55 of the 63 the raised values have returned to normal levels after calciferol therapy. In the other eight patients the levels are still falling though they are not yet within normal limits. Of the 46 with normal bones, 40 had levels of serum alkaline phosphatase of less than 13 . Of the remaining six, three had levels of 17,18 , and 25 King-Armstrong units respectively, normal bone biopsies, and normal serum levels of 5-nucleotidase without evident cause; three aged 14, 15, and 17 years had levels between 13 and 17 KingArmstrong units which were considered normal for this age.

This initial survey suggested that a raised level of serum alkaline phosphatase might be a reliable sign of osteomalacia in adult coeliac disease.

RELATIONSHIP WITH BLOOD GROUP TYPE In healthy adults, total serum alkaline phosphatase levels tend to be higher in those of blood groups $\mathrm{O}$ and $\mathrm{B}$ than in those of group $\mathrm{A}$ and to a lesser extent than those of group AB (Bamford, Harris, Luffman, Robson, and Cleghorn, 1965). This higher level might be due to a larger contribution by intestinal alkaline phosphatase to the total value since secretors of groups $O$ and $B$ have been shown to have detectable intestinal phosphatase (Arfors, Beckman, and Lundin, $1963 a, b)$. If so, groups $O$ and $B$ might occur more frequently than expected among the patients with raised levels of alkaline phosphatase.

The distribution of blood groups of all 118 patients with adult coeliac disease has been compared with that of the different blood groups found in the area by the Birmingham Blood Bank (Table II).
In the whole group there was a slight preponderance to group $\mathrm{A}$ at the expense of group $\mathrm{O}$. Of the 14 coeliacs with levels of serum alkaline phosphatase

\section{TABLE II}

DISTRIBUTION OF BLOOD GROUPS IN ADULT COELIAC DISEASE AND IN PATIENTS WITH DIFFERENT LEVELS OF ALKALINE PHOSPHATASE

\begin{tabular}{|c|c|c|c|c|c|}
\hline \multirow{2}{*}{$\begin{array}{l}\text { No. of } \\
\text { Patients }\end{array}$} & \multirow{2}{*}{$\begin{array}{l}\text { Alkaline Phosphatase } \\
\text { (King-Armstrong units) }\end{array}$} & \multicolumn{4}{|c|}{ Blood Group } \\
\hline & & $A$ & $O$ & $B$ & $A B$ \\
\hline $\begin{array}{r}49 \\
14 \\
55\end{array}$ & $\begin{array}{l}<13 \\
13 \text { to } 17 \\
>17\end{array}$ & $\begin{array}{r}23 \\
5 \\
30\end{array}$ & $\begin{array}{r}17 \\
7 \\
21\end{array}$ & $\begin{array}{l}7 \\
1 \\
4\end{array}$ & $\begin{array}{l}2 \\
1 \\
0\end{array}$ \\
\hline \multicolumn{2}{|l|}{ Total } & 58 & 45 & 12 & 3 \\
\hline \multicolumn{2}{|c|}{$\begin{array}{l}\text { Expected (\%) } \\
19.789 \text { ABO group (Birmingham) }(\%)\end{array}$} & $\begin{array}{l}49 \cdot 6 \\
42 \cdot 1\end{array}$ & $\begin{array}{l}55 \cdot 4 \\
46 \cdot 1\end{array}$ & $\begin{array}{l}9 \cdot 4 \\
8 \cdot 2\end{array}$ & $\begin{array}{l}3 \cdot 6 \\
3 \cdot 1\end{array}$ \\
\hline
\end{tabular}

between 13 and 17 King-Armstrong units, seven were group $\mathrm{O}$, five group $\mathbf{A}$, and one each group $\mathrm{B}$ and group $\mathrm{AB}$. Of the 55 coeliacs with levels above 17 King-Armstrong units, 30 were group A, 21 group $\mathrm{O}$, and four group $\mathrm{B}$. Of the three patients with raised levels of serum alkaline phosphatase for no obvious reason, two were group $\mathbf{A}$ and one group $O$. On this evidence coeliac patients of any particular blood group were not more liable to develop osteomalacia or a raised level of serum alkaline phosphatase.

RELATIONSHIP WITH SECRETOR STATUS Intestinal alkaline phosphatase has been most frequently detected in the serum of normal people who are secretors. Of 54 patients with adult coeliac disease, 47 were secretors, an incidence comparable to that found in normal populations (Langman, Leuthold, Robson, Harris, Luffman, and Harris, 1966). Of the 47 secretors, 24 were group $O$ and five group B; 12 had normal levels of serum alkaline phosphatase. Hence it seemed unlikely that intestinal alkaline phosphatase made any significant contribution to the total level in coeliacs.

ALKALINE PHOSPHATASE ISOENZYME Of 20 patients, 14 were on a gluten-free diet and six on normal diet, both groups taking approximately $50 \mathrm{~g}$ fat per day. Serum was collected in the midafternoon. Seven patients had an intestinal band on electrophoresis and of these five were group $\mathbf{O}$ and two group $\mathbf{A}$; all were secretors (Table III). None of the three patients with an increased level of alkaline phosphatase of undetermined aetiology had an intestinal band. 
TABLE III

FREQUENCY DISTRIBUTION OF SERUM ALKALINE PHOSPHATASE ISOENZYME BAND IN 20 PATIENTS WITH ADULT COELIAC DISEASE

Negative Faint Present Increased

\begin{tabular}{cllll} 
& Negative & Faint & Present & Increased \\
\hline Secretors & & & & \\
Group A & 7 & - & 2 & 0 \\
0 & 2 & - & 5 & 0 \\
B & 1 & - & 0 & 0 \\
AB & 1 & - & 0 & 0 \\
Non-secretors & 2 & - & 0 & 0
\end{tabular}

EFFECT OF L-PHENYLALANINE ON SERUM ALKALINE PHOSPHATASE Fishman et al (1963) reported that L-phenylalanine inhibits human intestinal alkaline phosphatase but not that developed from liver, bile, bone, lung, kidney, or spleen. Tissue extracts from normal small intestinal mucosa, bone, and liver were obtained from fresh surgical operative specimens and prepared by simple crushing and pulping. The isoenzyme was extracted in sucrose. A crude crystalline calf brush border was also used (kindly given by

TABLE IV

EFFECT OF 0.01 M L-PHENYLALANINE ON TOTAL ALKALINE PHOSPHATASE

$\begin{array}{lll}\text { Initial Level } & \text { Final } & \text { Reduction } \\ \text { (King- } & \text { Level } & (\%) \\ \text { Armstrong } & & \\ \text { units) } & & \end{array}$

\begin{tabular}{lrrr}
\hline Intestinal extract & & & \\
$1: 50$ & 72 & 20 & 74 \\
$1: 50$ & 74 & 18 & 75 \\
$1: 100$ & 37 & 11 & 69 \\
Bone extract & 85 & 82 & 4 \\
Liver extract & 54 & 45 & 18 \\
Calf brush border & 112 & 42 & 63
\end{tabular}

Professor G. Hubscher, Department of Medical Biochemistry, University of Birmingham). The specificity of L-phenylalanine for inhibiting intestinal alkaline phosphatase is demonstrated in Table IV.

TABLE $\mathrm{V}$

EFFECT OF L-PHENYLALANINE ON SERUM LEVELS OF TOTAL ALKALINE PHOSPHATASE

\begin{tabular}{|c|c|c|c|c|c|c|}
\hline \multicolumn{2}{|c|}{ Patient } & \multirow{2}{*}{$\begin{array}{l}\text { Blood } \\
\text { Group }\end{array}$} & \multirow{2}{*}{$\begin{array}{l}\text { Secretor } \\
\text { Status }\end{array}$} & \multicolumn{3}{|c|}{ Alkaline Phosphatase } \\
\hline & & & & Intestinal & $\begin{array}{l}\text { Initia } \\
\text { Leve }\end{array}$ & $\begin{array}{l}\text { Final } \\
\text { Level }\end{array}$ \\
\hline 1 & A.B & 0 & + & Present & $20 \cdot 5$ & $19 \cdot 0$ \\
\hline 2 & I.L & $\mathbf{0}$ & + & Present & $12 \cdot 5$ & $11 \cdot 0$ \\
\hline 3 & E.P & 0 & + & Present & $23 \cdot 0$ & $19 \cdot 0$ \\
\hline 4 & J.S & $\mathbf{A}$ & + & Present & $7 \cdot 0$ & 6.5 \\
\hline 5 & E.S & $\mathbf{A}$ & + & Present & $14 \cdot 5$ & $13 \cdot 5$ \\
\hline \multirow[t]{2}{*}{6} & J.B & 0 & + & Present & $19 \cdot 0$ & $15 \cdot 0$ \\
\hline & & & & Mean & $16 \cdot 1$ & $14 \cdot 0$ \\
\hline 7 & M.B & AB & + & Absent & $16 \cdot 0$ & $10 \cdot 0$ \\
\hline 8 & H.L & A & + & Absent & $17 \cdot 5$ & $20 \cdot 5$ \\
\hline 9 & J.C & $\mathbf{A}$ & + & Absent & 3.5 & $4 \cdot 5$ \\
\hline 10 & E.S & $\mathbf{A}$ & + & Absent & $16 \cdot 5$ & $15 \cdot 0$ \\
\hline \multirow[t]{2}{*}{11} & R.C & 0 & + & Absent & 15.0 & 15.0 \\
\hline & & & & Mean & 13.6 & 13.0 \\
\hline
\end{tabular}

The effect of L-phenylalanine on the serum levels of alkaline phosphatase was determined in 11 patients, in six of whom an intestinal band was present (Table V). This latter group had their serum levels reduced by a mean of $2 \cdot 1$ King-Armstrong units, while in the other five patients without such a band the reduction was 0.6 units. Electrophoretic strips after the addition of L-phenylalanine to the serum showed that the intestinal band had disappeared.

The error in the determination of alkaline phosphatase by automation is $\pm 12 \%$; eg, 1 standard deviation around a serum level of 17 units is 1 unit. Though the figures suggest that the total alkaline phosphatase of secretors may contain a small component of intestinal isoenzyme, the numbers are too small for a definite conclusion.

SERUM 5-NUCLEOTIDASE ESTIMATION A review of 77 patients with adult coeliac disease or idiopathic steatorrhoea who died between 1945 and 1966 revealed that two died of liver failure (hepatic necrosis of unknown cause and subacute hepatitis) and three had early cirrhotic changes in the liver.

In only one of the 66 patients investigated in this series was the level of 5-nucleotidase elevated. This patient had a serum alkaline phosphatase level of 18 King-Armstrong units, and the liver was infiltrated with Hodgkin's disease.

It seemed likely, therefore, that liver dysfunction did not contribute to any significant degree to the total alkaline phosphatase until there was a complicating or coincidental disease.

\section{DISCUSSION}

The conclusion to be drawn from this survey is that total serum alkaline phosphatase provides a good screening method for determining the presence of metabolic bone disease. In adult coeliac disease this is osteomalacia. There is no evidence to suggest that either intestinal isoenzymes or liver alkaline phosphatase make any significant contribution to the serum levels. However, the development of increasing levels of serum alkaline phosphatase in a patient with adult coeliac disease who is under treatment, even with calciferol, indicates some additional complication, usually malignancy. One such case was reported elswhere (Cooke, Thompson, and Williams, 1969) and three others have been encountered in whom malignancy has developed and who showed such changes in alkaline phosphatase.

We are indebted to the Endowment Fund for Medical Research, United Birmingham Hospitals for the financial support of one of us (O.D.H.) and to Dr R. Gaddie and 
Dr J. K. Johnson for much helpful advice on the laboratory techniques.

\section{REFERENCES}

Arfors, K. E., Beckman, L., and Lundin, L. G. (1963a). Genetic variations of human serum phosphatase. Acta. genet. (Basel), $13,89-94$

(1963b). Further studies on the association between human serum phosphatase and blood groups. Ibid, 13, 366-368.

Bamford, K. F., Harris, H., Luffman, J. E., Robson, E. B., and Cleghorn, T. E. (1965). Serum-âkaline-phosphatase and the ABO blood-groups. Lancet, 1, 530-531.

Barnett, E., and Nordin, B. E. C. (1960). The radiological diagnosis of osteoporosis: a new approach. Clin. Radiol., 11, 166-174.

Boyd, W. C., and Shapleigh, E. (1954). Separation of individuals of any blood group into secretors and non-secretors by use of a plant agglutinin (Lectin). Blood, 9, 1195-1198.

Clark, B., and Porteous, J. W. (1963). The intracellular location and metal - ion activation of the alkaline $\beta$-glycerophosphatase of rabbit small intestine. Biochem. J., 88, 20-21.

Cooke, W. T. (1968). Adult coeliac disease. In Progress in Gastroenterology, edited by G. B. J. Glass. Grune and Stratton, New York.

- - Thompson, H., and Williams, J. A. (1969). Malignancy and adult coeliac disease. Gut, 10, 108-111.

Dent, C. E., Norris, T. St. M., Smith, R., Sutton, R. A. L., and Temperley, J. M. (1968). Steatorrhoea with striking increase of plasma-alkaline-phosphatase of intestinal origin. Lancet, 1, 1333-1336.
Ferguson, A., Watson, W. C., Maxwell, J. D., and Fell, G. S. (1968), Alkaline phosphatase levels in normal and diseased small bowel. Gut, 9, 96-98.

Fishman, W. H., Green, S., and Inglis, N. I. (1963). L-phenylalanine: an organ specific, stereospecific inhibitor of human intestinal alkaline phosphatase. Nature (Lond.), 198, 685-686.

Hill, P. G., and Sammons, H. G. (1966). An automated method for the determination of serum 5-nucleotidase. Clin. chim. Acta, 13, 739-745.

Holt, J. H., and Miller, D. (1962). The localization of phosphomonoesterase and aminopeptidase in brush borders isolated from intestinal epithelial cells. Biochim. biophys. Acta (Amst.), 58, 239-243.

Korner, N. H. (1962). Distribution of alkaline phosphatase in serum protein fractions. J. clin. Path., 15, 195-199.

Langman, M. J. S., Leuthold, E., Robson, E. B., Harris, J., Luffman, J. E., and Harris, H. (1966). Influence of diet on the 'intestinal' component of serum alkaline phosphatase in people of different ABO blood groups and secretor status. Nature (Lond.), 212, 41-43.

Pulvertaft, C. N., Luffman, J. E., Robson, E. B., Harris, H., and Langman, M. J. S. (1967). Isoenzymes of alkaline phosphatase in patients operated upon for peptic ulcer. Lancet., 1, 237-239.

Riecken, E. O., Stewart, J. S., Booth, C. C., and Pearse, A. G. E. (1966). A histochemical study on the role of liposomal enzymes in idiopathic steatorrhoea before and during a gluten-free diet. Gut, 7, 317-332.

Roberts, L. B. (1967). The normal ranges, with statistical analysis for seventeen blood constituents. Clin chim. Acta, 16, 69-78. 